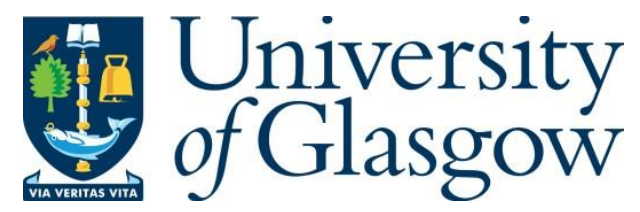

Claassen, C. (2019) Does public support help democracy survive? American Journal of Political Science

There may be differences between this version and the published version. You are advised to consult the publisher's version if you wish to cite from it.

This is the peer reviewed version of the following article, Claassen, C. (2019) Does public support help democracy survive? American Journal of Political Science, which has been published in final form at http://dx.doi.org/10.1111/ajps.12452. This article may be used for non-commercial purposes in accordance with Wiley Terms and Conditions for Self-Archiving.

http://eprints.gla.ac.uk/183785/

Deposited on: 10 April 2019

Enlighten - Research publications by members of the University of Glasgow http://eprints.gla.ac.uk 


\title{
Does Public Support Help Democracy Survive?
}

\author{
Christopher Claassen* \\ School of Social and Political Sciences, \\ University of Glasgow, \\ Glasgow G12 8QQ, UK \\ christopher.claassen@glasgow.ac.uk
}

April 2019

*Thanks to Patrick Bayer, Brian Fogarty, Sergiu Gherghina, Kelly Kollman, Robert Mattes, Lauren McLaren, William Mishler, Anja Neundorf, Vikki Turbine, Bernhard Reinsberg, Christian Welzel, and Karen Wright for helpful comments, and Jose Ricardo Villanueva Lira and Bryony MacLeod for excellent research assistance. I acknowledge the financial support of the Carnegie Trust for the Universities of Scotland. 


\title{
Does Public Support Help Democracy Survive?
}

\begin{abstract}
It is widely believed that democracy requires public support to survive. The empirical evidence for this hypothesis is weak, however, with existing tests resting on small cross-sectional samples and producing contradictory results. The underlying problem is that survey measures of support for democracy are fragmented across time, space, and different survey questions. In response, this article uses a Bayesian latent variable model to estimate a smooth country-year panel of democratic support for 135 countries and up to 29 years. The article then demonstrates a positive effect of support on subsequent democratic change, while adjusting for the possible confounding effects of prior levels of democracy and unobservable time-invariant factors. Support is, moreover, more robustly linked with the endurance of democracy than its emergence in the first place. As Lipset and Easton hypothesized over 50 years ago, public support does indeed help democracy survive.
\end{abstract}

Keywords: democracy, democratization, support for democracy, public opinion

Replication Materials: The data, code, and any additional materials required to replicate all analyses in this article are available on the American Journal of Political Science Dataverse within the Harvard Dataverse Network, at: https://doi.org/10.7910/DVN/HWLWOJ.

Words: 9,341 


\section{Introduction}

Democracy, once hegemonic on the world stage, is increasingly beleaguered. Democratic norms and institutions have visibly eroded in major democracies such as the United States, India, and Brazil (V-Dem Institute 2018b). Authoritarian-populist political movements have entered government in 11 European countries. 11 Ten democracies have failed since 2006 (Mechkova, Lührmann, and Lindberg 2017).

A prominent explanation for these ails is the "fading allure" of liberal democracy (Plattner 2017; see also Foa and Mounk 2016; 2017; Wilke and Fetterolf 2018). Indeed, a long tradition of political thought, extending back to Plato, holds that the vitality of democratic systems rests upon the attitudes and beliefs of the citizenry. Contemporary political scientists have elaborated this theory somewhat but agree with its basic contours: with public support, democracy is legitimate and stable; without such support, democracy is insecure and likely to fail should a crisis of some sort arise (e.g., Booth and Seligson 2009; Diamond 1999; Easton 1965; Lipset 1959; Mattes and Bratton 2007; Norris 2011; Rose, Mishler, and Haerpfer 1998).

Although this theory has been widely accepted by political scientists, it has received little rigorous empirical confirmation. The few existing tests (Fails and Pierce 2010; Hadenius and Teorell 2005; Inglehart 2003; Inglehart and Welzel 2005; Qi and Shin 2011; Welzel 2007) come to contradictory conclusions. These studies, moreover, all utilize small datasets of a few dozen countries observed at only one point in time. Yet without temporal variation it is very difficult to model dynamic processes like the trajectories of public support and democratization. Crosssectional designs additionally cannot account for unobservable country-specific confounds, such as the historical "critical junctures" which might co-determine paths of democratization and the development of a democratic political culture (Jamal and Kensicki 2016). The widespread accep-

${ }^{1}$ The Guardian. 2018. "Revealed: one in four Europeans vote populist." November 20, https://www. theguardian.com/world/ng-interactive/2018/nov/20/revealed-one-in-foureuropeans-vote-populist. 
tance of the theory of democratic support thus rests on fairly flimsy evidence.

This article therefore returns to the question of whether public support helps democracy to survive, offering two major advances over existing research. First, while existing studies use a fraction of the available survey data on support for democracy, I use all the data that has been collected by cross-national public opinion projects: 3,765 national opinions about democracy, obtained from 1,390 nationally-representative public opinion surveys, gathered by 14 survey projects, in 150 countries, over a period of 30 years. Because these data are heavily fragmented across time, country, and disparate survey items, a dynamic Bayesian latent variable model (Claassen 2019) is used to combine the shards of public opinion into one smooth measure of support for democracy. This panel dataset of democratic support affords a second advance over existing tests: with variation over time and country, it is possible to adjust both for the effects of unobserved country-specific confounds and for the influence of previous levels of democracy on current levels of support.

The analysis of this panel dataset shows that support for democracy is significantly and positively associated with subsequent change in democracy. Support is, moreover, more robustly linked with the endurance of democracy once it has been established, than with the emergence of democracy in the first place. In other words, as Lipset and Easton hypothesized over 50 years ago, public support does indeed help democracy survive.

\section{Public Support and Democracy}

\section{The Theory of Democratic Support}

The notion that democracy is rooted in the attitudes and orientations of the public has had an enduring appeal. Plato, for example, worried that democracy was prone to failure because the citizenry was unlikely to have the foresight or the inclination to hold leaders accountable. Many centuries later, at the dawn of modern political science, Lipset (1959) returned to this topic in a seminal paper. He argued that "political legitimacy" - the "belief that existing political institutions are the most appropriate or proper ones for the society" - is one of the principal "requisites" of 
stable democracy (Lipset 1959, 83).

This theory was extended and amplified by Easton $(1965 ; 1975)$ in another classic contribution. Easton distinguished between three "objects" that citizens might support. The most abstract of these objects is the nation or political community; the most concrete, the government and other political actors. Of interest here is Easton's intermediate object of support: the regime, or the basic rules and principles by which authority is wielded in a state.

Public support for the regime - i.e., public support for democracy - may then be diffuse or specific $1^{2}$ Specific support for democracy focuses on regime outputs and consequently has an instrumental quality, while diffuse support focuses on the principles of the regime and is therefore normative. Diffuse support is also more durable than specific support, helping to cushion regimes when political or economic crises strike. The concept of diffuse support for the regime thus closely resembles Lipset's notion of political legitimacy, but embeds the concept within a broader framework of public support.

This Lipset-Easton theory of democratic support offers a clear and compelling account of the link between the mass public and the dynamics of the political regime ${ }^{3}$ It argues that principled

${ }^{2}$ There is some disagreement regarding the conceptualization of diffuse and specific support. Some authors argue that support for particular political actors is necessarily specific, with support for the regime or nation being diffuse (e.g., Norris 2011); others argue that any of the three objects may be supported in a specific or diffuse fashion (e.g., Dalton 2004). What matters for the present discussion is that there is general agreement that principled, diffuse support for democracy is more likely to sustain democracy than instrumental, specific support.

${ }^{3}$ Inglehart and Welzel (Inglehart and Welzel 2005; Welzel 2013) offer an alternative conceptualization of democratic political culture emphasizing citizens' cultural values - such as liberty aspirations, toleration of difference, and trust in others - rather than their overt attitudes to democratic versus nondemocratic regimes. As such, instead of requiring explicit support for democracy, Inglehart and Welzel argue that democracy requires implicit support. This implicit conceptual- 
support for democracy helps ensure the survival of the regime. With such support, a democracy is legitimate and stable. Without it, democracy is unstable and liable to fail (Easton 1965; Mishler and Rose 1999).

\section{Existing Tests of the Theory}

Although the theory of democratic support has been widely accepted by political scientists (e.g., Bratton, Mattes, and Gyimah-Boadi 2005; Booth and Seligson 2009; Diamond 1999; Gibson 1996, Mattes and Bratton 2007; Norris 2011; Rose, Mishler, and Haerpfer 1998), it has received very little empirical attention. Most likely this is because the data which are required are far harder to obtain than the demographic or economic indices used to measure other determinants of democracy. An empirical test requires national measures of support for democracy, which, in turn, requires a costly, nationally-representative public opinion survey for each data point. Indeed, it was not until the groundbreaking inclusion of items measuring support for democracy on the third wave of the World Values Survey (WVS) that the relationship between support and democracy could even be empirically described.

In the first analysis of this data, Inglehart (2003) finds support to be modestly and positively correlated with democracy in a cross-sectional sample of 77 countries. Subsequent studies largely examine the same WVS data. Inglehart and Welzel (2005), for example, use a subsequent measure of democracy and control for years under democracy, but still find the same positive association between democratic support and democracy. In contrast, Hadenius and Teorell (2005) and Welzel (2007) show that support has little to no relationship with subsequent democracy once one adjusts for the the initial level of democracy, which they regard as necessary to counteract the possibility that democracy shapes political culture, rather than the reverse. Fails and Pierce (2010) add data from the Global Barometer projects and control for additional variables, but find no evidence that support is associated with either democratization or democratic survival. Finally, Qi and ization of support is sufficiently distinct from the explicit that I do not consider it further in this paper. 
Shin (2011) show that the level of public support for democracy is not associated with subsequent democracy when controlling for prior democracy and other covariates, but the level of "critical support" - the proportion of the public who both support democracy but are dissatisfied with its performance - is.

These studies reach markedly different findings, despite largely being re-analyses of the same WVS dataset. They also all use cross-sectional designs, which face two major limitations for testing the effects of support on democratic change. First, democratic systems inculcate support in their publics (Mattes and Bratton 2007; Mishler and Rose 2007; Rose, Mishler, and Haerpfer 1998), which implies that support is likely influenced by previous levels of democracy (Hadenius and Teorell 2005; Mattes and Bratton 2007; Pop-Eleches and Tucker 2017). However, crosssectional designs do not allow analysts to identify the effect of an independent variable when this variable is in part determined by previous realizations of the dependent variable.

Second, both democracy and support are likely shaped by idiosyncratic country-specific factors. Indeed, studies of democratization recognize the importance of key historical moments, or “critical junctures," which determined the paths by which both democracy and its purported determinants developed in particular countries (Acemoglu et al. 2008; Jamal and Kensicki 2016). For example, a country's colonial experience may have influenced its trajectory of democratization and also shaped its political culture (e.g., Diamond, Lipset, and Linz 1987; Rueschemeyer, Stephens, and Stephens 1992). It is not possible to adjust for such unobserved country-specific confounds using a cross-sectional research design.

Existing tests of the theory of democratic support are further limited by their reliance on a small fraction of the available opinion data, with small cross-sectional datasets of between 41 (Hadenius and Teorell 2005) and 86 countries (Fails and Pierce 2010). Yet with numerous crossnational survey projects now measuring support for democracy, there are are potentially thousands of observations to be gathered across countries and years. In addition, extant tests assume that support for democracy items are comparable across countries although research has demonstrated that survey questions have different meanings in different countries (Stegmueller 2011). Finally, these 
studies rely on the Freedom House index to measure democracy, which has received criticism for its measurement error, clustering of cases at the extremes of the scale, and methods of scoring and aggregating items (Alexander and Welzel 2011; Munck and Verkuilen 2002; Pemstein, Meserve, and Melton 2010). A more valid and reliable measure of liberal democracy is now available from the Varieties of Democracy project.

In sum, existing studies that test the theory of democratic support come to contradictory conclusions despite essentially analyzing the same dataset. These studies are moreover hampered by cross-sectional designs, small samples, and other limitations which undermine their ability to provide a dispositive test of the theory of democratic support. This is the task of this article.

\section{Hypotheses}

The theory of democratic support suggests a number of testable hypotheses, which are outlined and explicated in this section.

First, following existing studies (Hadenius and Teorell 2005; Inglehart 2003; Inglehart and Welzel 2005; Qi and Shin 2011; Welzel 2007), this article tests a general hypothesis that public support for democracy shapes subsequent changes in democracy, either by promoting democratization, or by preventing democratic backsliding. It assumes that the effect of support does not manifest immediately; an increase in support, in other words, is expected to produce pressure for future democratic change. The first hypothesis, H1, is as follows: Public support for democracy is positively associated with subsequent change in democracy.

Lipset's (1959) classic expression of the theory of democratic legitimacy focused on democratic systems, i.e., that support (or legitimacy) stabilizes and secures democracy when it already exists. Other analyses of democratization have similarly recognized that the factors which allow democracy to emerge may differ from those which help it to be sustained (e.g., Boix 2011; Fails \begin{tabular}{|l|l|l|l|l|}
\hline and Pierce 2010; Gleditsch and Ward 2006, Przeworski and Limongi 1997; Teorell 2010). This
\end{tabular} article follows suit, with the second and third hypotheses focusing on the role played by support in either the survival or the emergence of democracy. 
The second hypothesis, $\mathbf{H 2}$, pertains to the effect of support contingent on the existing level of democracy: public support for democracy in already-existing democracies is positively associated with subsequent change in democracy. In other words, support influences subsequent change in democracy only to the extent that some level of democracy already exists. When it does, change may then occur in either direction, with both increases and decreases in democracy possible. According to this hypothesis, support helps democracy to survive. A similar hypothesis has been proposed and tested by Acemoglu et al. (2009) with respect to development and democracy.

The final hypothesis focuses instead on the effects of support in autocratic systems. Although it has received less attention that the "supportive" role of support, a few scholars have proposed that democratic support may also function as democratic "demand" (Qi and Shin 2011). In this view, public support for democracy helps democracy to emerge in addition to (or instead of) helping it to survive. $\mathbf{H 3}$ proposes that support helps propel democratization in autocratic regimes: public support for democracy in autocracies is positively associated with subsequent change in democracy.

\section{Data}

\section{Measuring Democracy}

With at least ten different cross-national measures in existence (Pemstein, Meserve, and Melton 2010), democracy is perhaps the most-measured concept in social science. The sheer number of measures indicates the fragmentation of the market, with no single measure of democracy having won universal acceptance in the discipline. Indeed, even the three most widely-used measures - the democracy-autocracy index from Polity IV, the combined Freedom House (FH) index, and Przeworski and colleagues' (e.g., Przeworski and Limongi 1997) dichotomous DemocracyDictatorship (DD) indicator - have been subject to trenchant criticisms.

In particular, the minimalist Polity and DD measures have been criticized for neglecting the extent to which participation in the political process is widespread (Munck and Verkuilen 2002; 
Teorell et al. 2018), an important feature of democracy. Although the dichotomous nature of the DD indicator affords a conceptual clarity, Elkins (2000) show that it leads to lower validity and reliability. Continuous measures suffer from their own problems. Pemstein et al's (2010) latent variable model reveals that both the Polity and FH indices suffer from fairly high levels of measurement error. Both also cluster at extreme values, raising the concern that they are not finelygrained enough to pick up variation in highly democratic, or highly autocratic countries (Alexander and Welzel 2011; Teorell et al. 2018). Indeed, as Pemstein, Meserve, and Melton (2010) show, the Polity index exhibits a pronounced nonlinear relationship with a latent measure of democracy (see also Figure S1 in the supplementary materials). Criticism has furthermore been directed at the lack of clarity by which scores are assigned to indicators Munck and Verkuilen (2002), and also the use of generalists, rather than country specialists, to assign these scores (Pemstein, Meserve, and Melton 2010).

Without a clear solution to these issues, empirical scholars of democratization have stuck to using one or two of the big three measures. Fortunately, new measures of democracy provided by the Varieties of Democracy (V-Dem) project (Lindberg et al. 2014; Teorell et al. 2018; V-Dem Institute $2018 b$ ) allow us to progress beyond this impasse. The advantages of the V-Dem measures are fourfold.

First, V-Dem derive five conceptualizations of democracy from the extensive political theory literature on this topic: electoral, liberal, participatory, egalitarian, and deliberative democracy (Lindberg et al. 2014). Other, extant measures of democracy are based far more loosely, if at all, on extant theoretical conceptualizations.

Second, V-Dem then measures each of these conceptualizations in a more finely-grained fashion than existing democracy indices. They disaggregate each variety of democracy into its major sub-components, and measure these using multiple indicators. Ultimately V-Dem's liberal democracy index is measured with 69 indicators, compared with the 22 used for the combined Freedom House index and 4 used for the Democracy-Dictatorship indicator.

Third, V-Dem use country experts to code their indicators, rather than the in-house coders 
used by the Polity and Freedom House projects. Country specialists are well placed to rate various aspects of democracy in that country with which they are most familiar. Indeed, the Pemstein, Meserve, and Melton (2010) analysis of ten democracy measures suggests that those relying on specialists (e.g., the Bowman, Lehoucq, and Mahoney (2005) measures of democracy in Central America) have lower error variance than those relying on generalists (e.g., Polity and Freedom House) as well as those using objective data (Vanhanen's index). In addition, V-Dem gathers independent ratings from an average of five different country experts, which reduces the measurement error considerably (Teorell et al.2018).

Finally, V-Dem aggregates the indicators into subcomponents and democracy indices in a principled fashion. Items are combined into subcomponents using Bayesian factor analyses, which allows a test of whether they actually cohere as theory suggests (V-Dem Institute 2018c). The democracy indices are then assembled out of subcomponents using either a multiplicative or additive logic, as demanded by the particular conceptualization of democracy that is of interest.

Given these advantages in conceptualization and measurement, I use V-Dem data to measure democracy in this article. In particular, I use the V-Dem "liberal democracy index." This comprises a polyarchy, or "electoral democracy" index, which measures the political institutions “making rulers responsive to citizens ... through electoral competition for the electorate's approval," and a liberalism index, which captures the factors "protecting individual and minority rights against the tyranny of the state and the tyranny of the majority" (V-Dem Institute 2018a, 38). $4^{4}$

\section{Measuring Democratic Support}

Democratic support is measured using existing survey data. I collected nationally-aggregated responses to all the questions gauging public support for democracy that were available at the time of research. In particular, I selected survey questions focusing on diffuse support for democracy,

\footnotetext{
${ }^{4}$ The electoral democracy index is used as a robustness test, in results reported in the online supplementary materials.
} 
and gathered by cross-national survey projects fielding representative national samples of citizens. Relevant questions include those asking respondents to evaluate the appropriateness or desirability of democracy, to compare democracy to some undemocratic alternative, or to evaluate one of these undemocratic forms of government ${ }^{5}$

The following survey questions - all conceptually distinct from diffuse support for democracy - were excluded: (1) items calling for instrumental appraisals of democracy; (2) questions tapping respondents' trust in national political institutions (e.g., parliament); (3) items gauging support for previous political regimes (e.g., Communism); and (4) questions regarding the extent to which a country was in fact democratic. I also do not include questions regarding respondents' satisfaction with the performance of democracy, which is better regarded as a measure of specific support for democracy (Booth and Seligson 2009: Canache, Mondak, and Seligson 2001). Instead, I use satisfaction with democracy to provide a further test of the theory of democratic support ${ }^{6}$

Survey measures of support for democracy were available for 14 survey projects, 150 countries, and as far back in time as 1988.7 The resulting dataset of survey marginals is large in com-

${ }^{5} \mathrm{~A}$ list of included survey items is included in the online supplementary materials. Although these items are widely used to measure democratic support (e.g., Dalton 2004; Klingemann 1999; Mattes and Bratton|2007; Magalhães 2014; Norris 2011), they are not universally endorsed. Scholars such as Booth and Seligson (2009), Gibson (1996), Rose and Mishler (1996), and Svolik (2018) have proposed slightly different measures. These, however, have only been measured in a few countries at a few points in time.

${ }^{6}$ Similar methods are used to measure panels of satisfaction and support. Details regarding the former are presented in the online supplementary materials.

${ }^{7}$ Data are drawn from the following survey projects: the World and European Values Surveys, the Afrobarometer, Arab Barometer, Latinobarometer, Asiabarometer, Asian Barometer, South Asia Barometer, New Europe Barometer, Latin American Public Opinion Project, Eurobarometer, European Social Survey, Pew Global Attitudes Project, and the Comparative Study of Electoral 
parison with existing studies of the theory of democratic support, with 3,765 nationally-aggregated responses obtained from 1,390 nationally-representative survey samples. It is, however, fractured across time and space, with gaps in coverage for almost all countries. For example, in South Africa, cross-national survey projects fielded questions on support for democracy in 11 national surveys: the World Values Survey in 1996, 2001, 2006 and 2013, the Afrobarometer project in 1999, 2003, 2005, 2008, 2012, and 2015, and Pew Global Attitudes in 2002, 2013, and 2017. Despite this fairly regular polling, measures of South African democratic support are only available for 12 of the 22 years between 1996 and 2017 - and this is a case with above average coverage.

To make matters worse, the data are further fragmented across numerous survey questions. Indeed, there were as many as 52 different questions in the dataset, depending on how strictly I distinguished between items 8 Such fractured and unruly data are not easily combined into a single set of latent measures. Indeed, analysts' response to this fragmentation has generally been to discard most of the data and focus only on items collected by one survey project at one point in time, thus creating a small cross-national dataset (e.g., Inglehart and Welzel 2005; Qi and Shin 2011; Welzel 2007). Unfortunately, not only does this result in the neglect of interesting and useful temporal variation, it removes the additional information that is provided by other survey projects and items.

Instead, I use the dynamic Bayesian latent trait model measurement model developed by Claassen (2019). This model permits the measurement of a "smooth" country-year panel of public opinion that uses all available survey data, even when these are fragmented across space, time, and question wording. A brief overview of the model is provided below, with a formal expression and further discussion - in the online supplementary materials.

First, the model treats the observed number of respondents offering support for democracy

\section{Systems.}

${ }^{8}$ Two items fielded by different projects were always classed as distinct even if their wording appeared to be identical. This allows the model's item bias parameters to capture variation induced both by question wording and by idiosyncrasies in the methodology of the various survey projects. 
to each survey item as a binomially-distributed realization of a country- and time-varying latent variable of democratic support. The binomial probability parameter is further given a beta prior to allow for additional dispersion beyond that due only to sampling error.

Second, regardless of their actual commitment to democracy, respondents tend to agree more readily with some items than others. For example, the WVS question that asks respondents to evaluate whether "having a democratic political system" is a good way of governing their country is known to produce very high levels of agreement (Inglehart 2003; Klingemann 1999). Item bias parameters are included to adjust for these effects of survey item wording. These are comparable to intercepts in confirmatory factor analysis or item difficulty parameters in IRT models.

Third, the model also includes item by country bias parameters, which adjust for the varying effects of survey questions across countries. For example, some scholars have criticized survey questions that mention "democracy" because this word has slightly different meanings in different countries (Booth and Seligson 2009). Such items are therefore non-equivalent, which hampers the ability to make cross-national comparisons (Stegmueller 2011).9

Finally, each country's latent estimates are allowed to evolve over time. In particular, latent support for democracy in a particular country and year is treated as a function of the support estimated in the previous year plus some random noise. This dynamic component smooths opinion over time and allows the estimation of a particular country's democratic support even in years for which no survey data are available.

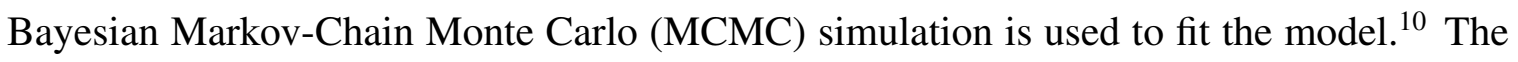
result is a smooth country-by-year panel of democratic support estimates. Although data are avail-

\footnotetext{
${ }^{9}$ Item by country parameters can be estimated along with item bias parameters and time-varying country latent estimates because the included survey items are generally fielded multiple times in any given country.

${ }^{10}$ Further details on priors, software, tests of convergence, and model checks are provided in the online supplementary materials.
} 
able for 150 countries and 30 years, the coverage of this panel is limited as follows. First, support is estimated only for the 137 countries in which at least two separate years of survey data were available. Second, estimates were removed for years prior to the year in which the first public opinion survey measuring support for democracy was fielded in each country. National time-series therefore commence the year support for democracy is first measured using a cross-national survey. Finally, because V-Dem data are not available for countries with populations of less than a million, Belize and Malta were dropped from the dataset. The result is a panel dataset of 2,435 support and democracy estimates, drawn from 135 countries, each with time-series ranging from four to 29 years. This dataset will be the focus of the remainder of the paper.

Claassen (2019) validates the latent variable model using held-out data. It proves to be more accurate than alternative methods, including country and item averages but also Caughey and Warshaw's (2015) "Grouped IRT" model. To further bolster confidence in the estimates of support for democracy, I plot all available estimates for two years, 2005 and 2015 (Figure 1), and discuss the geographic and temporal variation ${ }^{11}$ These choropleths support three conclusions.

First, support is higher where democracy has a long history - Western Europe, North America, and Australasia - and is lower in Asia and North Africa, where the heritage is authoritarian. This geographic pattern of support is consistent with existing research (e.g., Klingemann 1999, Rose, Mishler, and Haerpfer 1998; Norris 2011), which demonstrates the validity of the estimates. The fact that support is related to previous levels of democracy also confirms the suspicions of Hadenius and Teorell (2005) and Welzel (2007) that the effect of prior democracy on support should be considered when one estimates the effect of support on subsequent democratic change.

Second, a comparison of the choropleths reveal that support softened between 2005 and 2015 in some Western bastions of democracy, notably the USA and Canada. This trend is also consistent with other recent analyses (Foa and Mounk 2016; 2017). Since "signs of deconsolida-

${ }^{11}$ In the supplementary materials, I provide further discussion of the validity and unidimensionality of the latent estimates. I also provide similar plots showing national estimates of satisfaction with democracy. 
Figure 1. Mapping Support for Democracy
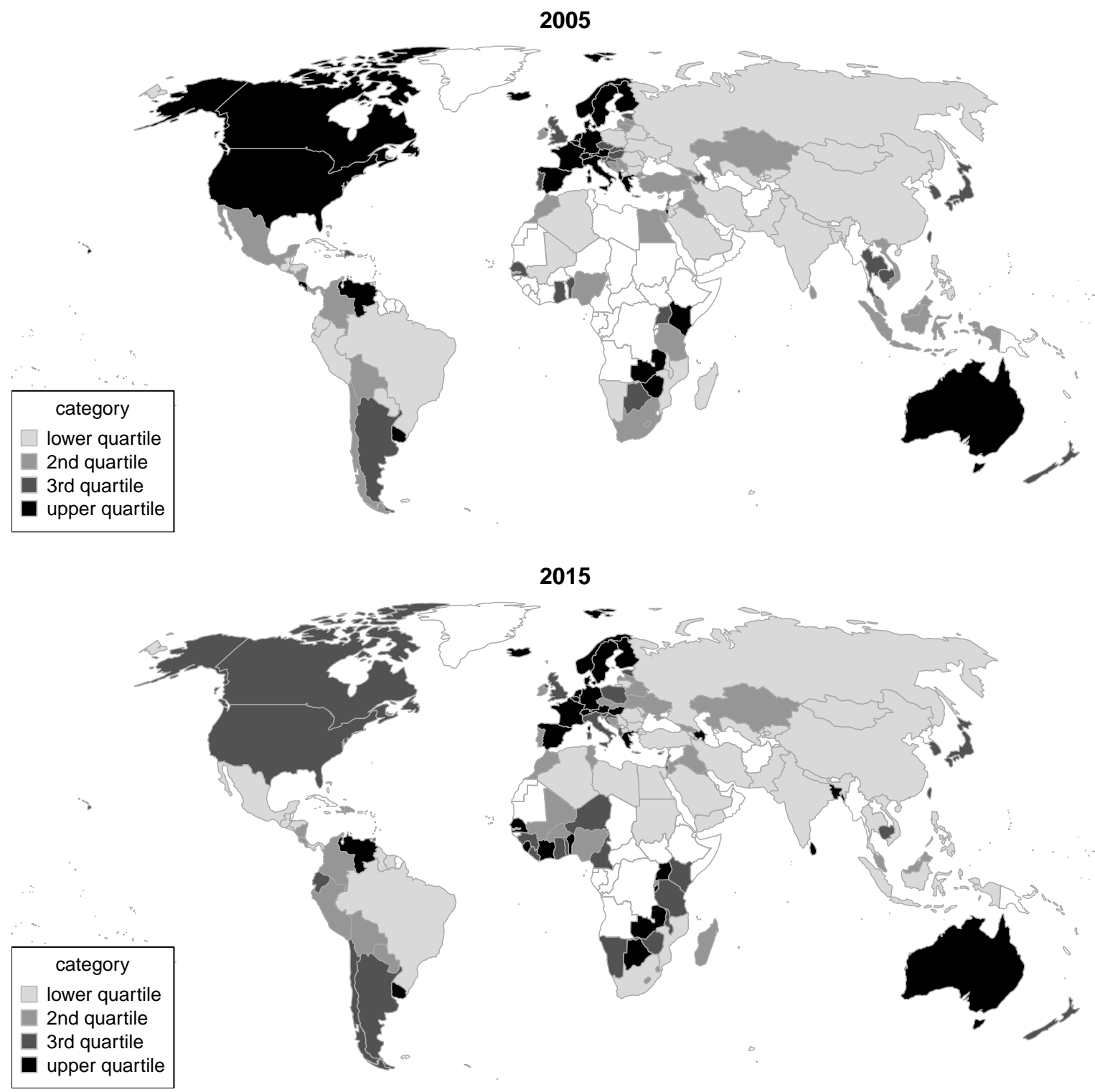

Estimates of democratic support in 2005 and 2015. Quartiles are calculated using data pooled across countries and years. Darker shades indicate countries with higher levels of support. Countries for which no estimates are available in the given year are shaded white.

tion" (Foa and Mounk 2017) do seem to be appearing in these countries, it is all the more urgent to test whether democracy does in fact require public support.

Third, quite the opposite trend is revealed in Africa, particularly in the South, East, and West: high - and indeed, rising - levels of democratic support in 2015. This pattern is yet another 
that echoes the findings of previous research (e.g., Bratton and Houessou 2014). In addition, it raises the question of whether higher African levels of democratic support could be a sign of democratic consolidation. These questions, of the consequences of support for democracy, are where I turn my attention next.

\section{Empirical Strategy}

How might one estimate the effect of support on democracy when both variables are persistent over time, jointly determined by third variables, both observable and unobservable, and prior levels of democracy are as likely to affect support as support is to affect democracy? This section explains how the causal effect of support on subsequent democracy will be identified, the assumptions made in doing so, and the econometric methods that will be used. It then considers how hypotheses 2 and 3, which focus on the effects of support contingent on the existing level of democracy, will be tested.

To crystallize the empirical strategy, I use causal graphs (e.g., Morgan and Winship 2015) 12 These are used to depict the relationship between democracy $\left(d_{i t}\right)$ and public support $\left(s_{i t}\right)$ in a panel set-up, where both variables vary across countries $i$ and years $t$ (Figure 2). The main hypothesis, that support exerts a causal effect on subsequent democracy, is indicated using a emboldened arrow.

\section{Identifying the Causal Effect of Support}

Graph (a), Figure 2, indicates a simple process by which support and democracy are interrelated over time and space. As can be seen, I assume that democracy and support are serially correlated, which is indicated by the arrows linking, e.g., $d_{i 1}$ to $d_{i 2}$. I also allow democracy to exhibit secondorder serial correlation (e.g., Teorell 2010), as indicated by the direct effect from $d_{i 1}$ to $d_{i 3}$. I further assume that there is no contemporaneous effect of support on democracy. A higher level of support,

${ }^{12}$ I closely follow the example of Imai and Kim (2019), who use graphs to describe the identification of causal effects in a panel data context. 
Figure 2. Causal Graphs of Support and Democracy

(a)

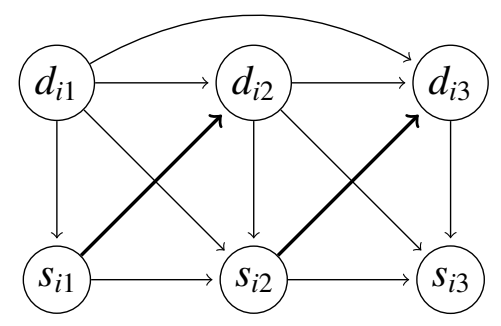

(b)

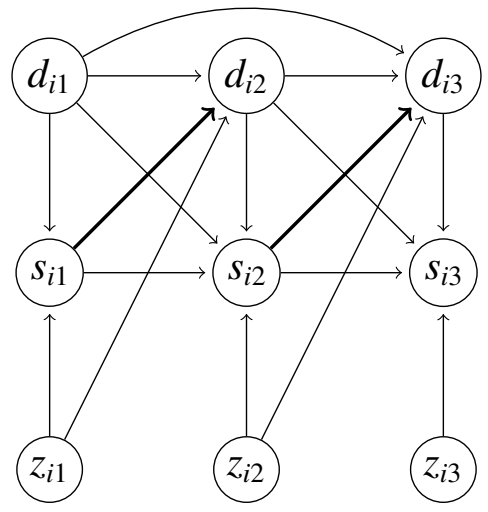

(c)

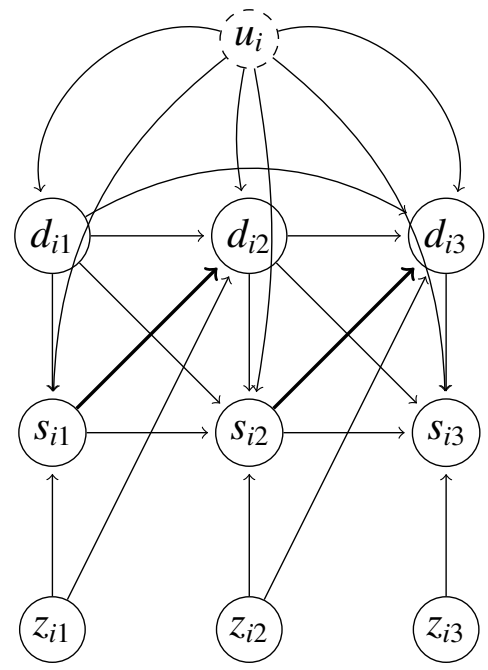

Causal graphs depicting three hypothetical data-generating processes whereby support $s_{i t}$ exerts a causal effect on subsequent democracy $d_{t+1}$, with $z_{i t}$ being an observed, time- and country-varying confounder, and $u_{i}$ being an unobserved time-invariant confounder. Bold arrows indicate the hypothesized causal effect of support on democracy; arrows indicate assumed causal effects. Solid circles indicate observed variables; dashed circles, unobserved.

in other words, takes some time to produce political change - if it ever does. Certainly it seems implausible that a higher level of support would exert an immediate effect on democracy. ${ }_{13}^{13}$

In addition, democracy likely influences the level of support, quite aside from any effect that latter might have on the former. I therefore include causal linkages from democracy to support in graph (a). Informed by the "thermostatic" model of policy opinion dynamics (Wlezien 1995), I assume that two particular effects are possible: support is influenced by immediate changes in democracy as much as prior levels of democracy. I indicate these two possible effects through the use of contemporaneous and lagged linkages between democracy and support. Under the assumptions of the data-generating process in graph (a), the causal effect of support on democracy

${ }^{13}$ It is a standard assumption, in empirical studies of democracy, that independent variables exert effects on subsequent levels of democracy (e.g., Acemoglu et al. 2009; Boix 2011; Teorell 2010; Welzel 2013). 
is given by the effect of $s_{i t-1}$ on $d_{i t}$, provided that one control for the first two lags of democracy $d_{i t-1}$ and $d_{i t-2}$.

Graph (b) then presents a more complex data-generating process with a third variable $z$ that confounds the observed relationship between democracy and support. For example, the level of economic development has been linked with the stabilization and emergence of democracy (Boix 2011; Przeworski and Limongi 1997), as well as the emergence of a democratic political culture (Inglehart and Welzel 2005). For the reasons outlined earlier, I assume again that there is no contemporaneous effect of $z_{i t}$ on $d_{i t}$, but, rather, this effect is lagged one year. I also assume that $z_{i t}$ influences $s_{i t}$ but not the reverse: this third variable is not affected by the level of support in other words. I furthermore assume no effect of $d_{i t}$ on $z_{i t}$, but this could be relaxed without consequence. Given these assumptions, estimating the causal effect of support on democracy requires adjusting for the effects of $d_{i t-1}, d_{i t-2}$, and $z_{i t-1}$.

The first tests of the effect of support on democracy in this article follow the assumptions of graph (b). These tests use the following linear model, which include two lags of democracy and a set of control variables $Z$ :

$$
d_{i t}=\alpha+\phi_{1} d_{i t-1}+\phi_{2} d_{i t-2}+\beta s_{i t-1}+\mathbf{Z}_{i t-1}^{\prime} \gamma+\epsilon_{i t}
$$

I include five control variables that plausibly determine both support and democracy. First, I use the log of GDP per capita to measure economic development, with data drawn from the World Bank World Development Indicators ${ }^{14}$ Second, economic growth - and in particular, economic crises - may also raise the risks of regime failure (Haggard and Kaufman 1995; Teorell 2010). I therefore calculate annual growth in GDP per capita using the GDP data. Third, dependence on natural resource revenues (Ross 2001) is measured using an indicator for whether a country received greater than $\$ 1,000$ per person in revenue from oil, natural gas, and minerals in

${ }^{14}$ The few missing values were imputed using linear models applied to GDP per capita data from the IMF and Penn World Tables. 
a given year ${ }^{15}$ Fourth, to capture the regional diffusion of democracy (Gleditsch and Ward 2006), I measure the average level of regional democracy for each year. ${ }^{16}$ Finally, some scholars have argued that democracy struggles to emerge in countries with an Islamic tradition, perhaps due to the political culture (e.g., Fish 2002). Although a time-invariant variable, I also include a measure of the proportion of a country identifying as Muslim in 1990.17

There is an additional threat to causal inference that remains to be considered: the confounding effects of unobservable, country-specific and time-invariant factors, indicated by $u$ in graph (c) (Figure 22. For example, as discussed earlier, "critical junctures" in national paths of political development may have influenced the current presence of democracy and the contemporary nature of the political culture (e.g., Acemoglu et al.2009). Estimating the causal effect of support on democracy under the assumptions of graph (c) requires adjusting not only for $d_{i t-1}, d_{i t-2}$, and $z_{i t-1}$, but also for $u_{i}$. When using panel data one can achieve the latter by including country fixed effects. This yields a dynamic fixed effects model, which is frequently used in empirical studies of democratization (e.g., Acemoglu et al. 2008; Boix|2011; Haber and Menaldo 2011). I similarly run additional tests of by adding country fixed effects $\mu_{i}$ to equation 1 :

$$
d_{i t}=\phi_{1} d_{i t-1}+\phi_{2} d_{i t-2}+\beta s_{i t-1}+\mathbf{Z}_{i t-1}^{\prime} \gamma+\mu_{i}+\epsilon_{i t}
$$

However, estimating such dynamic fixed effects models is problematic when time-series are short - as they are for many of the countries in my sample - because the lagged dependent

${ }^{15}$ The original data were drawn primarily from the World Bank World Development Indicators, supplemented with data from Haber and Menaldo (2011). A dichotomous indicator is used to allow the imputation of missing values within each country's time series. The revenue data are also zero-inflated and skewed, which contraindicates a continuous measure.

${ }^{16}$ I again use V-Dem Liberal Democracy index data with regions defined as United Nations subregions.

${ }^{17}$ Data sourced from the Pew Research Center. 
variable coefficient estimates are correlated with the error term $\epsilon_{i t}$. This produces a bias ("Nickell bias"), which grows as $T$ shrinks. A solution is to use a General Methods of Moments (GMM) estimator. In particular, when the dependent variable is strongly persistent, as it is here, Blundell and Bond's (1998) "system GMM" estimator is appropriate. This utilizes further lags of the dependent variable, in both levels and differences, as instruments for the independent variables (see, e.g., Freeman and Quinn 2012). I utilize the 3rd through 5th lags of democracy (in levels and differences) as instruments to estimate equation 2. I assume that these lags exert no direct effects on $d_{i t} 18$

\section{Identifying the Effects of Support on Democratic Survival and Democratic Emergence}

I have laid out a strategy for testing the causal effect of support on democracy and the assumptions made in doing so. However, the 2nd and 3rd hypotheses pertain to the effect of support in promoting the emergence versus survival of democracy, rather than general change in democracy. This section therefore describes the method with which I will test these differential effects of support on democracy.

When using a dichotomous measure of democracy, it is straightforward to model the differential effects of some determinant of democratization. A typical method is to implement a dynamic probit model with interactions between lagged democracy and the independent variables (e.g., Przeworski and Limongi 1997; Gleditsch and Ward 2006) 19 The marginal effect of each interaction term yields the effect of that independent variable in sustaining democracy, while the main effect gives the effect of that variable in driving a transition from autocracy to democracy.

The situation is more complicated when democracy is conceived and measured continuously, because both the initial level of democracy and the direction of any subsequent change may vary. In other words, a country that is democratic at time $t-1$ may become even more so at $t$, or, in-

${ }^{18}$ Since I have assumed that the second lag, i.e., $d_{i t-2}$ has a direct effect, it is unsuitable as an instrument and is therefore not included.

${ }^{19}$ This is sometimes described as a Markov transition model (e.g., Gleditsch and Ward 2006). 
stead, it may move toward autocracy. And vice versa for an autocracy. To estimate the differential effects of support in democratic versus autocratic systems, I use a method proposed by Acemoglu et al. (2009). This requires incorporating a regime type indicator $r_{i t}$, which takes a value of one if the country is democratic at time $t$ and zero otherwise. ${ }^{20}$ Equation 1 is adjusted as follows (and similarly for equation 2, which also includes country fixed effects):

$$
d_{i t}=\alpha+\phi_{1} d_{i t-1}+\phi_{2} d_{i t-2}+\beta^{d e m} s_{i t-1}\left(r_{i t-1}\right)+\beta^{a u t} s_{i t-1}\left(1-r_{i t-1}\right)+\mathbf{Z}_{i t-1}^{\prime} \gamma+\epsilon_{i t}
$$

The regime-type indicator $r_{i t}$ in effect produces two versions of the independent variable, democratic support. The first where support varies only if the regime is democratic at time $t$, otherwise taking a value of zero; the second where support varies only if the regime is autocratic at time $t$, otherwise taking a value of zero. There are consequently two parameters capturing the effects of level of support on democratic change. The first, $\beta^{\text {dem }}$, gives the effect of support when the starting point is a democracy; this parameter allows us to test $\mathrm{H} 2$. The second, $\beta^{\text {aut }}$, gives the effect of support when the starting point is an autocracy, which allows us to test $\mathrm{H} 3{ }^{21}$

\section{Results}

\section{Overall Effect of Support on Democracy}

I present first the tests of $\mathrm{H} 1$, in which the level of democratic support is expected to lead to democratic change, regardless of the initial level of democracy. Model 1,1 in Table 1 shows the results of a pooled OLS model corresponding to equation 1, which tests the overall effects of

\footnotetext{
${ }^{20}$ I use the "Regimes in the World" indicator from V-Dem, which utilizes the same items as the
} liberal democracy index but combines them in a slightly different fashion.

${ }^{21}$ An alternative method, used by Boix (2011) and Teorell (2010), is to create separate dependent variables of positive and negative changes in democracy (or upturns and downturns). I report the results of such models in the online supplementary materials. 
Table 1. Models of Support and Democracy

\begin{tabular}{|c|c|c|c|c|}
\hline & \multicolumn{4}{|c|}{ Dependent variable: Level of democracy } \\
\hline & \multicolumn{2}{|c|}{ Pooled OLS } & \multicolumn{2}{|c|}{ System GMM } \\
\hline & (1.1) & (1,2) & (1.3) & (1) 4$)$ \\
\hline Democracy $_{t-1}$ & $\begin{array}{l}1.141^{*} \\
(.080)\end{array}$ & $\begin{array}{c}1.142^{*} \\
(.080)\end{array}$ & $\begin{array}{l}1.091^{*} \\
(.079)\end{array}$ & $\begin{array}{l}1.095^{*} \\
(.083)\end{array}$ \\
\hline Democracy $_{t-2}$ & $\begin{array}{r}-.163^{*} \\
(.080)\end{array}$ & $\begin{array}{r}-.164^{*} \\
(.079)\end{array}$ & $\begin{array}{r}-.203^{*} \\
(.051)\end{array}$ & $\begin{array}{r}-.200^{*} \\
(.050)\end{array}$ \\
\hline Support $_{t-1}$ & $\begin{array}{c}.264^{*} \\
(.094)\end{array}$ & & $\begin{array}{c}.881^{*} \\
(.366)\end{array}$ & \\
\hline Support $_{t-1}$, democracies only & & $\begin{array}{c}.318^{*} \\
(.108)\end{array}$ & & $\begin{array}{r}.810^{*} \\
(.344)\end{array}$ \\
\hline Support $_{t-1}$, autocracies only & & $\begin{array}{l}.090 \\
(.210)\end{array}$ & & $\begin{array}{c}.917 \\
(.672)\end{array}$ \\
\hline Log GDP per capita ${ }_{t-1}$ & $\begin{array}{l}.015 \\
(.123)\end{array}$ & $\begin{array}{c}.001 \\
(.130)\end{array}$ & $\begin{array}{l}.388^{*} \\
(.174)\end{array}$ & $\begin{array}{l}.366^{*} \\
(.186)\end{array}$ \\
\hline GDP per capita growth ${ }_{t-1}$ & $\begin{array}{c}.007 \\
(.017)\end{array}$ & $\begin{array}{c}.007 \\
(.017)\end{array}$ & $\begin{array}{c}-.016 \\
(.020)\end{array}$ & $\begin{array}{c}-.014 \\
(.021)\end{array}$ \\
\hline Regional democracy $_{t-1}$ & $\begin{array}{c}.008 \\
(.005)\end{array}$ & $\begin{array}{c}.008 \\
(.004)\end{array}$ & $\begin{array}{c}.055^{*} \\
(.028)\end{array}$ & $\begin{array}{c}.051 \\
(.030)\end{array}$ \\
\hline Percent Muslim & $\begin{array}{c}-.002 \\
(.003)\end{array}$ & $\begin{array}{r}-.002 \\
(.003)\end{array}$ & $\begin{array}{c}-.014 \\
(.009)\end{array}$ & $\begin{array}{c}-.013 \\
(.009)\end{array}$ \\
\hline Resource dependence $_{t-1}$ & $\begin{array}{l}-.367 \\
(.244)\end{array}$ & $\begin{array}{l}-.367 \\
(.242)\end{array}$ & $\begin{array}{r}-1.196 \\
(.683)\end{array}$ & $\begin{array}{r}-1.128 \\
(.694)\end{array}$ \\
\hline Intercept & $\begin{array}{c}.647 \\
(.947)\end{array}$ & $\begin{array}{c}.765 \\
(.998)\end{array}$ & & \\
\hline$N$ observations & 2435 & 2435 & 2435 & 2435 \\
\hline$N$ countries & 135 & 135 & 135 & 135 \\
\hline$N$ instruments & & & 122 & 124 \\
\hline Residual standard error & 3.056 & 3.055 & & \\
\hline Adjusted $\mathrm{R}^{2}$ & .986 & .985 & & \\
\hline Wooldridge AR(1) test (p-value) & .769 & .882 & & \\
\hline Hansen test (p-value) & & & .438 & .469 \\
\hline Arellano-Bond AR(2) test (p-value) & & & .560 & .546 \\
\hline
\end{tabular}

${ }^{*} p<.05$. Pooled OLS models include Beck-Katz panel-corrected standard errors in parentheses. Standard errors for System GMM models incorporate the Windmeijer correction. Democracy is measured using the V-Dem Liberal Democracy index and is scaled from 0 to 100. Support is standardized. 
support on subsequent democracy under the assumptions of data-generating process (b) in Figure 2 . These results indicate that support is positively and significantly related to subsequent democratic change. ${ }^{22}$

One concern with such a model is possible serial correlation due to the temporal persistence of democracy. Including two lags of the dependent variable appears to have resolved this problem, as indicated by the insignificant ( $p=0.77$ ) Wooldridge test for serial correlation. A second concern is cross-sectional correlation across countries and heteroscedasticity within countries (Beck and Katz 1995). I include Beck-Katz panel-corrected standard errors to adjust for these possibilities.

In addition, as discussed earlier, this model does not take account of unobserved timeinvariant factors which might affect the relationship between support and democracy. Model 13 , Table 1 does; it corresponds to equation 2, which focuses only on the within-country effect of support on democracy. In particular, Model 13 is estimated using the system GMM method. As can be seen, the estimated short-run effect of support on democracy remains positive and significant in this GMM set up.

GMM models are fairly sensitive to the number of lags used to create instruments. Roodman (2009) therefore suggests limiting the number of instruments to no more than the number of cross-sectional units (countries). I follow this advice by using only the 3rd through 5th lags of democracy as instruments. A Hansen test $(p=0.44)$ indicates that the instruments are jointly valid. An Arellano-Bond test $(p=0.56)$ shows that there is no second-order serial correlation, meaning that I do not have to resort to using more distant lags.

The pooled OLS estimate of the short-run effect of support on subsequent democracy is 0.26 , with the GMM estimate being somewhat higher (0.88). Since the measure of democracy has a theoretical scale that ranges from 0 to 100 , both effects are fairly small in the short term. Yet the dynamic nature of both models allows us to estimate both short and long-run effects (De Boef and Keele 2008). According to Model 11, a permanent one-standard-deviation increase in democratic

${ }^{22}$ Because I have included lagged dependent variables, we can interpret the effect of support as pertaining to subsequent change in democracy (see, e.g., De Boef and Keele 2008). 
support is expected to lead to an increase in democracy of 12.12 units (95\% CI [6.43, 19.63]) in the long run ${ }^{23}$ Despite the larger short run effect of support estimated by the GMM model (Model 1.3), its long-run estimate is lower, at 7.83 (95\% CI [4.30, 15.91]).

To demonstrate the long run effects of support on democracy, I plot the simulated effects of a one standard deviation increase in democracy in Figure 3. Such a plot is not straightforward when using dynamic models, because the predicted effects at time $t$ feed forward to become lagged independent variables at time $t+1$. To do so, I set all independent variables to a moderate value and allow the system to run for 200 years. I then increase the level of democracy from the mean level to one standard deviation above the mean, and allow the system of equations to run for a further 30 years. To capture the uncertainty inherent in the model, I use a method of dynamic simulation outlined by Williams and Whitten (2012) ${ }^{24}$

The first panel in Figure 3 shows the simulated effects on democracy when support increases by one standard deviation (from 0 to 1 ), which implies a moderate but not dramatic increase (the model used is Model 11.1). Following the increase in support, in year 0, democracy increases slowly but steadily over the ensuing years. After 30 years, democracy is 6.42 units higher, which

${ }^{23}$ The formula for the long run effect is $\beta /\left(1-\left(\phi_{1}+\phi_{2}\right)\right)$. The estimate and confidence intervals are generated by simulating 10,000 multivariate normal distributions with expectation being the model coefficients and the variance being the Beck-Katz panel corrected variance-covariance matrix.

${ }^{24}$ In particular, I create multiple perturbed vectors of model coefficients by taking 10,000 draws from a multivariate normal distribution with expectation being the vector of model coefficients and variance being the Beck-Katz covariance matrix: $\tilde{\Theta} \sim \operatorname{MVN}\left(\Theta, \Sigma^{B K}\right)$. When predicting effects using each of the $i$ simulated vectors of $k$ coefficients, I add additional noise as estimated by the regression standard error: $\tilde{Y}_{i} \sim N\left(X_{k} \tilde{\Theta}_{k i}, \sigma\right)$. I therefore do not use GMM results, for which regression standard error estimates are unavailable. Finally, I use the mean value of $\tilde{Y}_{i}$ as the point estimate for that year, and the 0.025 and 0.975 quantiles of $\tilde{Y}_{i}$ as the lower and upper confidence bounds. 
Figure 3. Simulated Long-Run Effects of Support on Democracy
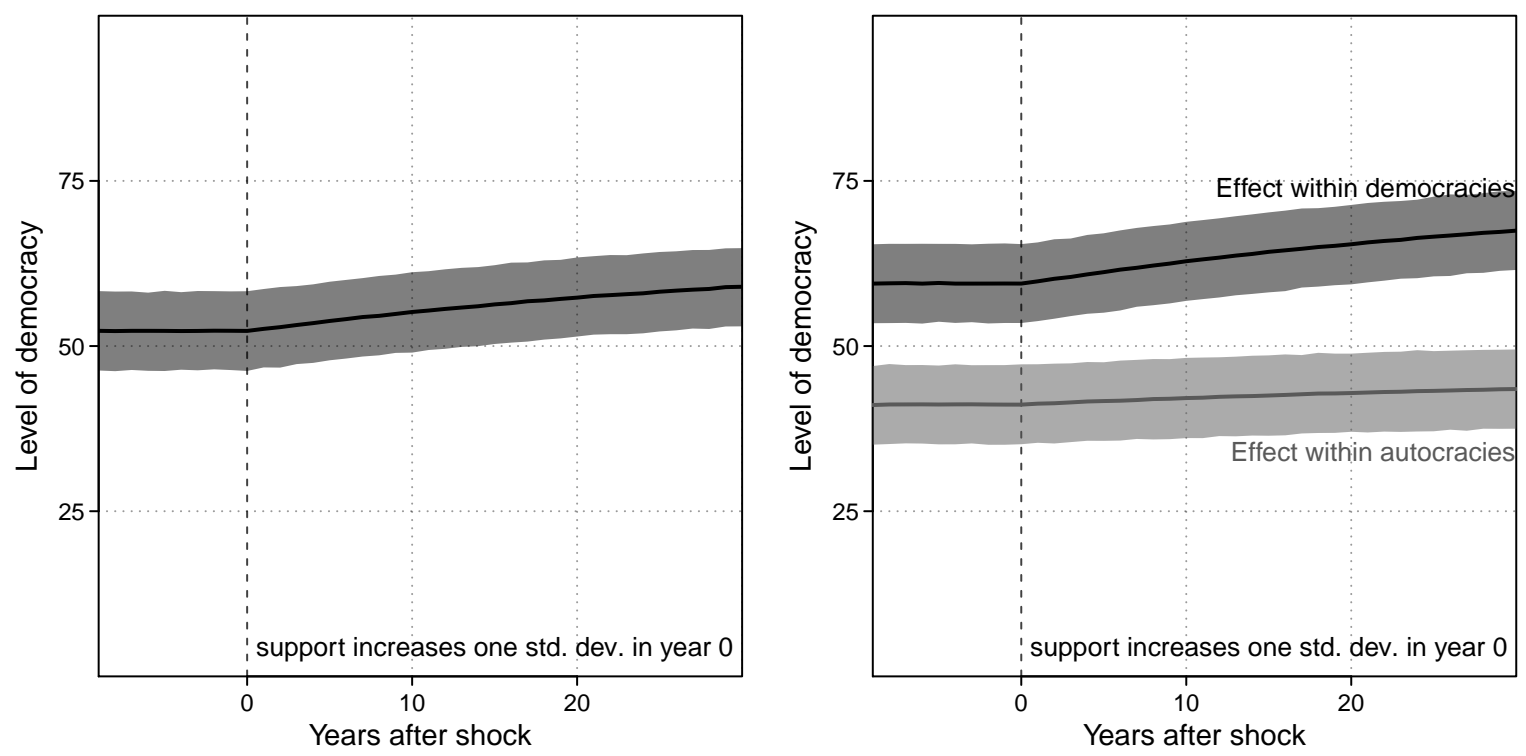

Simulated effects are estimated using coefficients from models 1,1 and 1,2 . The solid lines indicate the mean simulated effect; the shaded regions indicate the $95 \%$ confidence intervals of these simulated effects.

represents slightly more than half the long-run effect discussed earlier.

This simulation is, of course, extremely hypothetical. Political systems would hardly hold still for three decades while the effects of an increase in public support feed through the system. Yet this exercise demonstrates an important point. While changes in democratic support have a small effect in the short run, this effect accumulates over the long run. Changes in public support for democracy continue to exert an influence on political regimes for many years.

In sum, I find evidence that support for democracy is positively associated with subsequent change in democracy. This finding resonates with earlier, cross-sectional research by Inglehart (2003) and Inglehart and Welzel (2005), but stands in contrast to the null findings of Hadenius and Teorell (2005) and Welzel (2007). However, this analysis goes substantially further than previous studies since the evidence is drawn from a much larger sample of countries and years. In particular, the temporal dimension of the data allows me to both model the dynamic relationships between support and democracy and adjust for the effects of unobserved country-specific confounders. 


\section{Effects of Support on Democratic Emergence and Survival}

The results presented thus far suggest a general relationship between support and democracy. I now examine more specific processes that might underpin such a general relationship. In other words, is support linked with democracy by aiding its emergence or its survival? To examine these more specific processes, I turn to my tests of hypotheses 2 and 3.

Model 1.2 and Model 11.4 (Table 11) follow Acemoglu et al. (2009) in separately estimating the effects of support within democratic versus autocratic regimes. I again utilize both pooled OLS and system GMM methods to test these hypotheses. Results from both specifications tell a similar story: within democracies, support is positively and significantly associated with subsequent change in democracy; within autocracies, the effect is insignificant, although still positive. The GMM results again indicate a stronger short term effect of support than the pooled OLS results. In sum, the evidence from my data is consistent with $\mathrm{H} 2$, but not consistent with $\mathrm{H} 3$.

In the second panel of Figure 3 , I then display the long run effects of an increase in support in a hypothetical democratic (black line) and autocratic (grey line) country. Both effects are estimated using Model 1 2. The effect of support is even more pronounced when it is examined within democracies: after 30 years, the simulated regime is 7.67 units more democratic. For comparison, the full long run effect, calculated from the results of Model[1.2, is 14.78 (95\% CI [7.39, 26.78]). The effect of support is noticeably weaker in autocracies, with the full long run effect being 4.08 (95\% CI $[-23.02,24.41])$.

In the online supplementary materials I consider additional model specifications. First, I include a measure of corruption as an additional time-varying covariate in both the pooled OLS and system GMM models. Second, I follow Teorell (2010) and Boix (2011) in creating separate dependent variables of upturns and downturns in democracy. Third, I employ the interactive fixed effects models proposed by Bai (2009) for unobservable confounds with heterogenous over-time effects on different countries. Finally, I use a more minimal measure of democracy - V-Dem's "electoral democracy index" - as the dependent variable. All these additional models show evidence consistent with $\mathrm{H} 2$, i.e., support aids in sustaining democracy. There is no evidence for the 
Table 2. Models of Support, Satisfaction, and Democracy

\begin{tabular}{|c|c|c|c|c|}
\hline & \multicolumn{4}{|c|}{ Dependent variable: Level of democracy } \\
\hline & \multicolumn{2}{|c|}{ Pooled OLS } & \multicolumn{2}{|c|}{ System GMM } \\
\hline & 2.1) & 22) & (2) 3$)$ & 2.4) \\
\hline Support $_{t-1}$ & $\begin{array}{c}.281^{*} \\
(.103)\end{array}$ & & $\begin{array}{c}.697^{*} \\
(.303)\end{array}$ & \\
\hline Support $_{t-1}$, democracies & & $\begin{array}{c}.294^{*} \\
(.113)\end{array}$ & & $\begin{array}{c}.660^{*} \\
(.293)\end{array}$ \\
\hline Support $_{t-1}$, autocracies & & $\begin{array}{c}.104 \\
(.224)\end{array}$ & & $\begin{array}{c}.654 \\
(.607)\end{array}$ \\
\hline Satisfaction $_{t-1}$ & $\begin{array}{c}-.098 \\
(.074)\end{array}$ & & $\begin{array}{c}-.053 \\
(.134)\end{array}$ & \\
\hline Satisfaction $_{t-1}$, democracies & & $\begin{array}{c}.000 \\
(.096)\end{array}$ & & $\begin{array}{c}.016 \\
(.167)\end{array}$ \\
\hline Satisfaction $_{t-1}$, autocracies & & $\begin{array}{r}-.302 \\
(.161) \\
\end{array}$ & & $\begin{array}{r}-.187 \\
(.249) \\
\end{array}$ \\
\hline$N$ observations & 2278 & 2278 & 2278 & 2278 \\
\hline$N$ countries & 126 & 126 & 126 & 126 \\
\hline$N$ instruments & & & 124 & 128 \\
\hline Residual standard error & 3.077 & 3.075 & & \\
\hline Adjusted $\mathrm{R}^{2}$ & .985 & .985 & & \\
\hline Wooldridge $\mathrm{AR}(1)$ test (p-value) & .894 & 670 & & \\
\hline Hansen test ( $p$-value) & & & .563 & .593 \\
\hline Arellano-Bond AR(2) test (p-value) & & & .561 & .567 \\
\hline
\end{tabular}

${ }^{*} p<.05$. All models include two lags of democracy and the covariates specified in Table 1 Pooled OLS models include Beck-Katz panel-corrected standard errors in parentheses; standard errors for System GMM models incorporate the Windmeijer correction. Democracy is measured using the VDem Liberal Democracy index and is scaled from 0 to 100. Support and satisfaction are standardized.

democratizing effect of support (H3), and mixed evidence for the overall effect (H1).

In sum, the findings of the analyses suggest that the effect of support is concentrated in systems that are already democratic. In other words, while support appears to help sustain democracy, it does not appear to help autocracies democratize.

\section{Effects of Satisfaction on Democracy}

Finally, I consider the role played by satisfaction with the performance of democracy. This measure captures citizens' evaluations of the performance of the system as a whole as well as the incumbent government of the time (Booth and Seligson 2009: Canache, Mondak, and Seligson 2001), and is 
therefore a more instrumental and specific form of support. It may be the case that the favorable effects of support that we have observed are due to such instrumental approval of performance rather than any principled commitment to democracy. In this section I therefore test whether democratic support helps sustain democracy over and above any supportive effects exerted by democratic satisfaction.

I replicate my models from Table 1, in both the pooled OLS and system GMM specifications, but now adding satisfaction to the equations. These are presented in Table 2. Satisfaction does not show a positive and significant effect on subsequent democracy, regardless of whether the pooled OLS or system GMM model is used, or whether its effects are examined within democracies or autocracies. Support, however, continues to exhibit a significant effect on democracy, and one that is of similar magnitude to those reported in Table 1.

These results suggest two findings which are consistent with Lipset-Easton theory of democratic support. First, specific support for democracy exerts little or no independent effect on the rise or fall of democracy. Second, diffuse support helps sustain democratic regimes, and it does so quite aside from any specific support that democracy may attract due to instrumental performance evaluations.

\section{Conclusion}

From Latin America to Western Europe, and from Africa to North America, democracy is under attack from authoritarian and populist leaders. The findings described in this article are consistent with a classic theory for why this might occur - the support afforded to democracy by the public. As scholars have long argued, if support is low, emerging democracies might fail to consolidate, or even descend into autocracy. Moreover, although Western democracies were thought to have consolidated, and thus escaped this purgatory, the evidence presented here bolsters recent warnings that declining support for democracy might lead to even established democracies failing, or becoming "deconsolidated" (Foa and Mounk 2016, 2017; Plattner 2017).

However, the findings of this article are not consistent with another hypothesis regarding 
public support for democracy: that it functions also as "demand for democracy," spurring further democratization (Qi and Shin 2011). Thus, although public support may help bolster and defend already-existing democratic rights and institutions, it does not appear to push elites to establish or expand these rights and institutions. This is perhaps not terribly surprising. While political competition makes democracies at least somewhat responsive to public opinion - including opinion about whether the regime should be democratic or not - autocratic elites are arguably less pressured by popular sentiments. They also are more willing and able to suppress popular demands if need be.

In order to test the effects of support on democracy I gathered an expansive database of over 3,000 nationally-aggregated opinions, and estimated a smooth country-by-year panel of democratic support that varies over 135 countries and up to 29 years. This dramatically increased the available data on support, with variation now over time as well as space. Yet by the standards of, for example, the literature on development and democracy, these data are still quite limited in geographic and temporal range. In particular, survey measures of support for democracy began in earnest only after the third wave of democracy crested in the early 1990s. As a consequence, we cannot ascertain whether these findings pertain to previous periods of democratic decline, such as the "reverse wave" seen in the 1960s and 1970s. Indeed, the literature on development and democracy has shown that the link between the two has varied considerably over time (e.g., Boix 2011; Acemoglu et al.2009).

This article has also been silent on the mechanisms by which public support bolsters democracy and lack of support undermines it. Perhaps low support for democracy allows populist and undemocratic leaders to emerge (Foa and Mounk 2016; Plattner 2017); in contrast, when such leaders attempt to undermine democratic procedures, perhaps high support triggers collective action by an outraged public (Booth and Seligson 2009). Given the current challenges to democracy, these are crucial questions for scholars to investigate. 


\section{References}

Acemoglu, Daron, Simon Johnson, James A. Robinson, and Pierre Yared. 2008. "Income and Democracy." American Economic Review 98(3): 808-842.

Acemoglu, Daron, Simon Johnson, James A. Robinson, and Pierre Yared. 2009. "Reevaluating the Modernization Hypothesis.” Journal of Monetary Economics 56(8): 1043-1058.

Alexander, Amy C., and Christian Welzel. 2011. "Measuring Effective Democracy: The Human Empowerment Approach.” Comparative Politics 43(3): 271-289.

Bai, Jushan. 2009. "Panel Data Models With Interactive Fixed Effects.” Econometrica 77(4): 1229_ 1279.

Beck, Nathaniel, and Jonathan N. Katz. 1995. "What To Do (And Not To Do) With Time-Series Cross-Section Data." American Political Science Review 89(3): 634-647.

Blundell, Richard, and Stephen Bond. 1998. "Initial Conditions and Moment Restrictions in Dynamic Panel Data Models.” Journal of Econometrics 87(1): 115-143.

Boix, Carles. 2011. "Democracy, Development, and the International System.” American Political Science Review 105(4): 809-828.

Booth, John A., and Mitchell A. Seligson. 2009. The Legitimacy Puzzle in Latin America: Political Support and Democracy in Eight Nations. Cambridge: Cambridge University Press.

Bowman, Kirk, Fabrice Lehoucq, and James Mahoney. 2005. "Measuring Political Democracy: Case Expertise, Data Adequacy, and Central America." Comparative Political Studies 38(8): 939-970.

Bratton, Michael, and Richard Houessou. 2014. "Demand for Democracy Is Rising in Africa, But Most Political Leaders Fail to Deliver." Afrobarometer Policy Paper No. 11. http://afrobarometer.org/sites/default/files/publications/Policy\%20paper/ ab_r5_policypaperno11.pdf. 
Bratton, Michael, Robert Mattes, and E. Gyimah-Boadi. 2005. Public Opinion, Democracy, and Market Reform in Africa. Cambridge, UK: Cambridge University Press.

Canache, Damarys, Jeffery J. Mondak, and Mitchell A. Seligson. 2001. "Meaning and Measurement in Cross-National Research on Satisfaction with Democracy.” Public Opinion Quarterly 65(4): 506-528.

Caughey, Devin, and Christopher Warshaw. 2015. "Dynamic Estimation of Latent Opinion Using a Hierarchical Group-Level IRT Model.” Political Analysis 23(2): 197-211.

Claassen, Christopher. 2019. “Estimating Smooth Country-Year Panels of Public Opinion.” Political Analysis 27(1): 1-20.

Dalton, Russell J. 2004. Democratic Challenges, Democratic Choices: The Erosion of Political Support in Advanced Industrial Democracies. Oxford: Oxford University Press.

De Boef, Susanna, and Luke Keele. 2008. “Taking Time Seriously.” American Journal of Political Science 52(1): 184-200.

Diamond, Larry. 1999. Developing Democracy: Towards Consolidation. Baltimore: Johns Hopkins University Press.

Diamond, Larry, Seymour Martin Lipset, and Juan Linz. 1987. "Building and Sustaining Democratic Government in Developing Countries: Some Tentative Findings.” World Affairs 150(1): 519.

Easton, David. 1965. A Systems Analysis of Political Life. New York: Wiley.

Easton, David. 1975. "A Re-Assessment of the Concept of Political Support." British Journal of Political Science 5(4): 435-457.

Elkins, Zachary. 2000. “Gradations of Democracy? Empirical Tests of Alternative Conceptualizations." American Journal of Political Science 44(2): 293-300.

Fails, Matthew D., and Heather Nicole Pierce. 2010. "Changing Mass Attitudes and Democratic 
Deepening." Political Research Quarterly 63(1): 174-187.

Fish, M. Steven. 2002. "Islam and Authoritarianism.” World Politics 55(1): 4-37.

Foa, Roberto Stefan, and Yascha Mounk. 2016. "The Danger of Deconsolidation: The Democratic Disconnect." The Journal of Democracy 27(3): 5-17.

Foa, Roberto Stefan, and Yascha Mounk. 2017. “The Signs of Deconsolidation.” Journal of Democracy 28(1): 5-16.

Freeman, John R., and Dennis P. Quinn. 2012. "The Economic Origins of Democracy Reconsidered." American Political Science Review 106(1): 58-80.

Gibson, James L. 1996. “'A Mile Wide But an Inch Deep'(?): The Structure of Democratic Commitments in the Former USSR." American Journal of Political Science 40(2): 396-420.

Gleditsch, Kristian, and Michael D. Ward. 2006. "Diffusion and the International Context of Democratization." International Organization 60(4): 911-33.

Haber, Stephen, and Victor A. Menaldo. 2011. "Do Natural Resources Fuel Authoritarianism? A Reappraisal of the Resource Curse.” American Political Science Review 105(1): 1-26.

Hadenius, Axel, and Jan Teorell. 2005. "Cultural and Economic Prerequisites of Democracy: Reassessing Recent Evidence.” Studies in Comparative International Development 39(4): 87106.

Haggard, Stephen, and Robert Kaufman. 1995. The Political Economy of Democratic Transitions. Princeton, NJ: Princeton University Press.

Imai, Kosuke, and In Song Kim. 2019. "When Should We Use Unit Fixed Effects Regression Models for Causal Inference with Longitudinal Data?" American Journal of Political Science https://doi.org/10.1111/ajps.12417.

Inglehart, Ronald. 2003. "How Solid is Mass Support for Democracy - and How Can We Measure It?" PS: Political Science E Politics 36(1): 51-57. 
Inglehart, Ronald, and Christian Welzel. 2005. Modernization, Cultural Change, and Democracy: The Human Development Sequence. Cambridge: Cambridge University Press.

Jamal, Amal, and Anna Kensicki. 2016. "A Theory of Critical Junctures for Democratization: A Comparative Examination of Constitution-Making in Egypt and Tunisia." Law E Ethics of Human Rights 10(1): 185-222.

Klingemann, Hans-Dieter. 1999. "Mapping Political Support in the 1990s: A Global Analysis.” In Critical Citizens: Global Support for Democratic Governance, ed. Pippa Norris. Oxford, UK: Oxford University Press.

Lindberg, Staffan I., Michael Coppedge, John Gerring, Jan Teorell, Daniel Pemstein, Eitan Tzelgov, Yi ting Wang, Adam Glynn, David Altman, Michael Bernhard, Steven Fish, Alan Hicken, Matthew Kroenig, Kelly McMann, Pamela Paxton, Megan Reif, Svend-Erik Skaaning, and Jeffrey Staton. 2014. "V-Dem: A New Way to Measure Democracy.” Journal of Democracy 25(3): 159-169.

Lipset, Seymour Martin. 1959. "Some Social Requisites of Democracy: Economic Development and Political Legitimacy." American Political Science Review 53(1): 69-105.

Magalhães, Pedro C. 2014. “Government Effectiveness and Support for Democracy.” European Journal of Political Research 53(1): 77-97.

Mattes, Robert, and Michael Bratton. 2007. "Learning about Democracy in Africa: Awareness, Performance, and Experience.” American Journal of Political Science 51(1): 192-217.

Mechkova, Valeriya, Anna Lührmann, and Staffan I. Lindberg. 2017. "How Much Democratic Backsliding?" Journal of Democracy 28(4): 162-169.

Mishler, William, and Richard Rose. 1999. "Five Years After the Fall: Trajectories of Support for Democracy in Post-Communist Europe." In Critical Citizens: Global Support for Democratic Governance, ed. Pippa Norris. Oxford, UK: Oxford University Press.

Mishler, William, and Richard Rose. 2007. "Generation, Age, and Time: The Dynamics of 
Political Learning during Russia's Transformation." American Journal of Political Science 51(4): 822-834.

Morgan, Stephen L., and Christopher Winship. 2015. Counterfactuals and Causal Inference: Methods and Principles for Social Research. 2nd ed. New York: Cambridge University Press.

Munck, Gerardo L., and Jay Verkuilen. 2002. “Conceptualizing and Measuring Democracy: Evaluating Alternative Indices." Comparative Political Studies 35(1): 5-34.

Norris, Pippa. 2011. Democratic Deficit: Critical Citizens Revisited. Cambridge: Cambridge University Press.

Pemstein, Daniel, Stephen Meserve, and James Melton. 2010. "Democratic Compromise: A Latent Variable Analysis of Ten Measures of Regime Type.” Political Analysis 18(4): 426-49.

Plattner, Marc F. 2017. “Liberal Democracy’s Fading Allure.” Journal of Democracy 28(4): 5-14.

Pop-Eleches, Grigore, and Joshua A. Tucker. 2017. Communism's Shadow: Historical Legacies and Contemporary Political Attitudes. Princeton, NJ: Princeton University Press.

Przeworski, Adam, and Fernando Limongi. 1997. "Modernization: Theories and Facts." World Politics 49(2): 155-183.

Qi, Lingling, and Doh Chull Shin. 2011. "How Mass Political Attitudes Affect Democratization: Exploring the Facilitating Role Critical Democrats Play in the Process." International Political Science Review 32(3): 245-262.

Roodman, David. 2009. "A Note on the Theme of Too Many Instruments." Oxford Bulletin of Economics and Statistics 71(1): 135-158.

Rose, Richard, and William Mishler. 1996. "Testing the Churchill Hypothesis: Popular Support for Democracy and Its Alternatives.” Journal of Public Policy 16(1): 29-58.

Rose, Richard, William Mishler, and Christian Haerpfer. 1998. Democracy and Its Alternatives: Understanding Post-Communist Societies. Baltimore: Johns Hopkins University Press. 
Ross, Michael L. 2001. “Does Oil Hinder Democracy?” World Politics 53(3): 325-361.

Rueschemeyer, Dietrich, Evelyne Huber Stephens, and John D. Stephens. 1992. Capitalist Development and Democracy. Chicago, IL: University of Chicago Press.

Stegmueller, Daniel. 2011. "Apples and Oranges? The Problem of Equivalence in Comparative Research.” Political Analysis 19(4): 471-487.

Svolik, Milan. 2018. "When Polarization Trumps Civic Virtue: Partisan Conflict and the Subversion of Democracy by Incumbents.” Working Paper, Yale University, https://campuspress. yale.edu/svolik/files/2018/09/polarization_manuscript-2ex9y63.pdf.

Teorell, Jan. 2010. Determinants of Democratization: Explaining Regime Change in the World, 1972-2006. Cambridge: Cambridge University Press.

Teorell, Jan, Michael Coppedge, Staffan Lindberg, and Svend-Erik Skaaning. 2018. "Measuring Polyarchy Across the Globe, 1900-2017." Studies in Comparative International Development forthcoming, https://doi.org/10.1007/s12116-018-9268-z.

V-Dem Institute. 2018a. “Codebook: v8 - April 2018." V-Dem Institute, University of Gothenburg, https://www.v-dem.net/media/filer_public/64/ad/64ad9308-45fa-473e$8 \mathrm{e} 2 \mathrm{~b}-\mathrm{e} 1 \mathrm{c} 0 \mathrm{c} 4 \mathrm{e} 421 \mathrm{e} 6 / \mathrm{v}-\mathrm{dem} \_$codebook_v8.pdf.

V-Dem Institute. 2018b. "Democracy for All? V-Dem Annual Democracy Report 2018.” VDem Institute, University of Gothenburg, https://www.v-dem.net/media/filer_public/3f/19/ 3f19efc9-e25f-4356-b159-b5c0ec894115/v-dem_democracy_report_2018.pdf.

V-Dem Institute. 2018c. "Methodology, v8." V-Dem Institute, University of Gothenburg, $\quad$ https://www.v-dem.net/media/filer_public/5a/f1/5af198e9-f3e8-4619-b9fda8387fdc22a5/v-dem_methodology_v8.pdf.

Welzel, Christian. 2007. “Are Levels of Democracy Affected by Mass Attitudes? Testing Attainment and Sustainment Effects on Democracy." International Political Science Review 28(4): 397-424. 
Welzel, Christian. 2013. Freedom Rising: Human Empowerment and the Quest for Emancipation. Cambridge: Cambridge University Press.

Wilke, Richard, and Janell Fetterolf. 2018. "Liberal Democracy's Crisis of Confidence.” Journal of Democracy 29(4): 136-150.

Williams, Laron K., and Guy D. Whitten. 2012. "But Wait, There's More! Maximizing Substantive Inferences from TSCS Models." Journal of Politics 74(3): 685-693.

Wlezien, Christopher. 1995. "The Public as Thermostat: Dynamics of Preferences for Spending." American Journal of Political Science 39(4): 981-1000. 